Article

\title{
Adsorption and Photocatalytic Study of Phenol Using Composites of Activated Carbon Prepared from Onion Leaves (Allium fistulosum) and Metallic Oxides $\left(\mathrm{ZnO}\right.$ and $\left.\mathrm{TiO}_{2}\right)$
}

\author{
Diego Felipe Hernández-Barreto ${ }^{1}$, Jenny Paola Rodriguez-Estupiñán ${ }^{1, *}$, \\ Juan Carlos Moreno-Piraján ${ }^{1, * \mathbb{D}}$, Rocío Sierra Ramírez ${ }^{2}$ and Liliana Giraldo ${ }^{3}$ \\ 1 Facultad de Ciencias, Departamento de Química, Universidad de los Andes, Bogotá 111711, Colombia; \\ df.hernandez14@uniandes.edu.co \\ 2 Facultad de Ingeniería, Departamento de Ingeniería Química, Universidad de los Andes, Bogotá 111711, \\ Colombia; rsierra@uniandes.edu.co \\ 3 Facultad de Ciencias, Departamento de Química, Universidad Nacional de Colombia, Bogotá 111711, \\ Colombia; lgiraldogu@unal.edu.co \\ * Correspondence: jp.rodrigueze@uniandes.edu.co (J.P.R.-E.); jumoreno@uniandes.edu.co (J.C.M.-P.)
}

Received: 20 April 2020; Accepted: 13 May 2020; Published: 20 May 2020

\begin{abstract}
The aim of this study was to evaluate and compare the adsorption and photocatalytic activity of activated carbon-based photocatalysts. Titanium dioxide $\left(\mathrm{TiO}_{2}\right)$ and zinc oxide $(\mathrm{ZnO})$ were chosen as semiconductors to prepare composites with activated carbon by the wet impregnation method. Activated carbon was prepared using as starting material onion leaves (Allium fistulosum) and as activating agent phosphoric acid $\left(\mathrm{H}_{3} \mathrm{PO}_{4}\right)$. Photooxidation and batch adsorption of phenol was studied to compare the efficiency of the materials prepared. The results showed that the composite $\mathrm{AC}-\mathrm{TiO}_{2}$ has a greater photocatalytic activity and a better adsorption capacity compared to $\mathrm{AC}-\mathrm{ZnO}$ composite.
\end{abstract}

Keywords: adsorption; photocatalysis; activated carbon; graphene; composites

\section{Introduction}

Colombia is a country characterized by its extensive agricultural activity. A very common and important vegetable in Colombian diet and cuisine is onion (Allium fistulosum). It is known as "cebolla junca" or "cebolla larga", and it is principally produced in the Department of Boyacá. According to the National Administrative Department of Statistics (DANE), in 2014 more than 200 thousand tons were produced in Boyacá, which means around $70 \%$ of the total production in Colombia during that year [1]. In general, the plant is composed of roots, stem and leaves, but only the stem is used for cooking. Consequently, the leaves and roots are discarded, generating big amounts of waste, since they represent $25-30 \%$ of the weight of the plant. That means that these residues have a waste-to-product potential that must be exploited. One way to take advantage of that potential is to use it as a precursor of carbonaceous materials such as activated carbon.

Activated carbons (AC) are versatile materials that are widely studied due to their striking characteristics such as high surface areas, high adsorption potential, specific surface properties, thermal stability, mechanical and electrical properties, low acid/base reactivity, and controllable pore structure [2]. Another important characteristic is that they are usually obtained from wastes that come from different sources. Lignocellulosic biomass such as fruit shell [3], seeds [4], leaves [5], bagasse [6], peels [7], and other forestry and agricultural byproducts [8] are the most common raw materials for 
activated carbon preparation. However, there are other starting materials that have been studied like tire rubber [9], animal bones [10], and different types of coal [11]. Two processes are commonly used to prepare AC, namely physical and chemical activation, the latter being the method that allows better porosity [12]. In physical activation, the raw material is gasified by an oxidant atmosphere at high temperature and pressure, while in chemical activation, the precursor is impregnated with a chemical agent (e.g., $\mathrm{H}_{3} \mathrm{PO}_{4}, \mathrm{ZnCl}_{2}, \mathrm{KOH}$ ), followed by activation at medium-high temperatures [13]. AC are mainly used as adsorbent in water treatment, in gas separation-purification processes [14], and in energy storage [15].

In resent research, the application of AC mainly as support material for heterogeneous catalysis has been reported [16-18]. Due to its high surface area, it enhances dispersion and minimizes sintering of catalysts, resulting in higher catalytic efficiencies. Photocatalysis is a photoinduced reaction in which a semiconductor (catalyst) is irradiated with UV-Vis light to produce reactive oxygen species (ROS) that can oxidize other molecules [19]. Therefore, this type of catalysis has attracted widespread attention due to its potential to degrade water pollutants. One of the most popular photocatalysts is titanium dioxide $\left(\mathrm{TiO}_{2}\right)$, which is categorized as a n-type semiconductor [20]. In addition, zinc oxide $(\mathrm{ZnO})$ is also a very common semiconductor used in photocatalysis. Both materials have important characteristics such as high stability, low cost, non-toxicity, similar band gap, and high photocatalytic activity [21]. However, there are some drawbacks to using these materials, such as high recombination rates of electron-hole pairs, and the difficulty in recovery from water after treatment, due to its small particle size (25-30 nm) [22]. As a consequence, recent research has focused on new methodologies to solve this problem, synthesizing composites with materials like graphene [23,24], metal-organic frameworks [25,26], hydroxyapatite [27,28] and activated carbon [29,30]. Some studies have shown that a remarkable synergy is achieved between adsorption and photocatalysis in water pollutant removal [31].

Another new carbon-based material is graphene and its derivatives. Graphene is directly related to graphite in that graphite is composed of many graphene layers. The term "graphene" is normally used for single layer materials, but also for graphene with a few layers. Both are carbon allotropes, characterized by an hexagonal lattice arrangement, composed of $\mathrm{sp}^{2}$ hybridized carbon atoms [32]. This implies that carbon atoms are connected to each other by $\sigma$ bonds formed by electrons in valence orbitals $\left(2 \mathrm{~s}, 2 \mathrm{p}_{\mathrm{x}}\right.$, and $\left.2 \mathrm{p}_{\mathrm{y}}\right)$ [33]. This material exhibits novel properties, such as huge specific surface area, high mechanical strength, thermal conductivity, and excellent electronic properties [34]. The interesting electronic properties of graphene can be attributed to the fourth valence electron of carbon atoms, which is in the $2 p_{z}$ orbital. This orbital is oriented perpendicular to $\sigma$ bonds, and it can overlap with other $2 p_{z}$ orbitals of neighboring atoms, resulting in delocalized $\pi$ and $\pi^{*}$ bands [33]. As for the applications of graphene, it is widely used as a supercapacitor [35], in photo and optoelectronic devices [36], in wastewater treatment [37], in gas storage [38], and in photocatalysis [24], among others. Some graphene modifications and derivatives have been synthetized to improve its performance in different fields. For example, graphitic carbon nitride $\left(\mathrm{g}-\mathrm{C}_{3} \mathrm{~N}_{4}\right)$ has been used as an efficient photocatalyst for hydrogen production and other environmental applications $[39,40]$ due to its low cost, environmental nontoxic precursors, narrow band gap, and chemical and thermal stability.

Considering the waste-to-product potential of onion leaves, activated carbon was prepared using this lignocellulosic biomass as starting material. The AC was then used to obtain composites with $\mathrm{TiO}_{2}$ and $\mathrm{ZnO}\left(\mathrm{AC}-\mathrm{TiO}_{2}\right.$ and $\mathrm{AC}-\mathrm{ZnO}$, respectively) by the wet impregnation method. Adsorption and photocatalytic activity were studied and compared, evaluating phenol removal and photooxidation in aqueous media. In addition, a bibliography review was made to compare the results obtained with those obtained by other authors that use graphene and its derivatives as adsorbent and photocatalyst for phenol removal. 


\section{Results and Discussion}

\subsection{Characterization of Materials}

\subsubsection{Physical Characterization}

Nitrogen physisorption isotherms $(77 \mathrm{~K})$ of the three materials $\left(\mathrm{AC}, \mathrm{AC}-\mathrm{TiO}_{2}\right.$, and $\left.\mathrm{AC}-\mathrm{ZnO}\right)$ are presented in Figure 1. As can be seen, the AC isotherm showed a hysteresis loop so it could be classified as a type IVa isotherm. According to IUPAC [41], this indicates the presence of capillary condensation and thus, mesoporosity in the carbon structure. As it could be observed, composite isotherms presented a different shape and were classified as Type II isotherms. Changes in the shape of the isotherms reflected changes in textural and structural properties of the $\mathrm{AC}$ after $\mathrm{TiO}_{2}$ and $\mathrm{ZnO}$ incorporation. Loss of the hysteresis loop is notorious and is due to mesoporous filling with metal oxides after impregnation. To study textural and structural characteristics of the solids, mathematical models were applied to raw adsorption data, such as Brunauer-Emmet-Teller (BET) and quenched solid density functional theory (QSDFT).
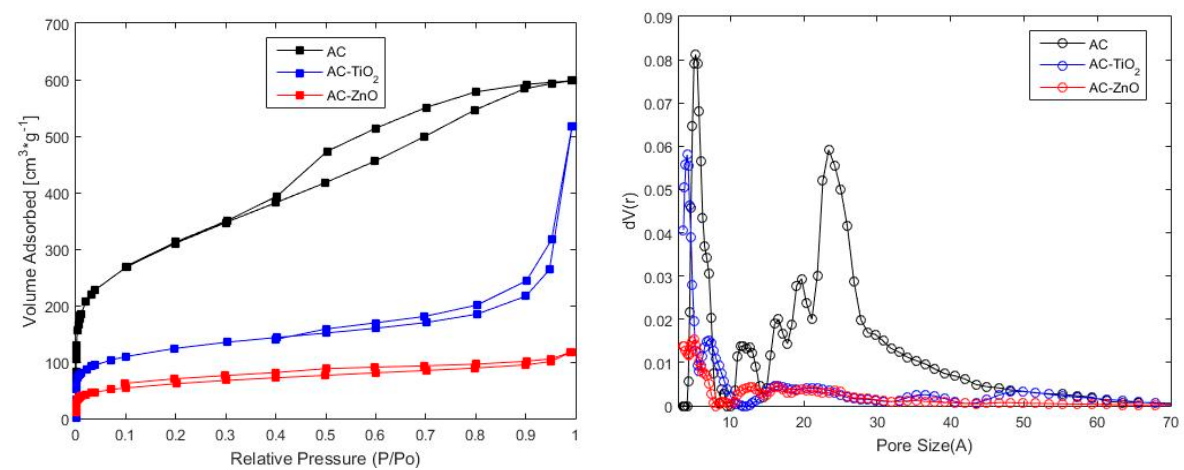

Figure 1. From left to right, nitrogen isotherms $(77 \mathrm{~K})$ and pore size distribution (PSD) calculated using the density functional theory (DFT) method.

The pore size distribution (PSD) of each material is presented in Figure 1. PSDs were obtained by the QSDFT method assuming slit-cylindrical pore geometry. Mesoporosity was contained in AC (20-50 ̊) and it also presented a microporous structure, mainly between 5 and $15 \AA$. Meanwhile, composites presented mostly micropores $(<20 \AA)$ and a few mesopores, indicating that mesopores in pristine AC were filled by metallic oxides, leaving only a microporous structure that was also partially occupied. In addition, a decrease in BET specific surface area and pore volume (Table 1) showed that, in fact, there was pore filling in the carbon structure. According to these results, it is possible to predict that the AC will present a higher adsorption capacity.

Table 1. BET and Quenched Solid Density Functional Theory (QSDFT) parameters.

\begin{tabular}{ccccc}
\hline \multirow{2}{*}{ Material } & \multicolumn{2}{c}{ BET } & \multicolumn{2}{c}{ QSDFT } \\
\cline { 2 - 5 } & $\mathbf{S}_{\text {BET }}\left(\mathbf{m}^{\mathbf{2}} * \mathbf{g}^{-\mathbf{1}}\right)$ & $\mathbf{C}$ (Energy Constant) & $\mathbf{V}_{\text {pore }}\left(\mathbf{c m}^{\mathbf{3}} * \mathbf{g}^{-\mathbf{1}}\right)$ & Half Pore Width $(\AA)$ ) \\
\hline $\mathrm{AC}$ & 1100 & 203.1 & 0.879 & 5.25 \\
$\mathrm{AC}-\mathrm{TiO}_{2}$ & 440 & 267.0 & 0.557 & 4.09 \\
$\mathrm{AC}-\mathrm{ZnO}$ & 218 & 253.8 & 0.158 & 5.03 \\
\hline
\end{tabular}

In Figure 2, powder X-ray diffraction (PXRD) results are presented. There was no presence of diffraction peaks in the AC diffractogram due to its amorphous structure. However, a thick band appeared between 22 and $30^{\circ}$, distinctive of the graphite turbostratic structure present in AC [42]. Conversely, diffractions peaks appeared in $\mathrm{AC}-\mathrm{TiO}_{2}$ and $\mathrm{AC}-\mathrm{ZnO}$ diffractograms as a result of the crystalline structure of the semiconductors impregnated over the AC surface. Diffraction peaks 
obtained were in agreement with those reported in the literature for anatase-rutile and wurtzite, which are the most stable and common crystalline phases of $\mathrm{TiO}_{2}$ and $\mathrm{ZnO}$, respectively [43-45]. It is important to point out that the raw titanium dioxide used had a molar anatase:rutile ratio of 1.7:0.3, which means that diffraction peaks of both crystalline phases were present in the diffractogram.

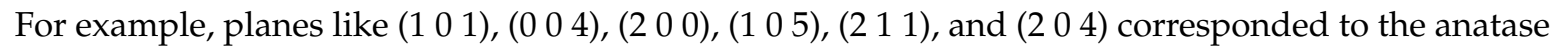
phase, while (2 00$),(220),(116)$, and (2 15$)$ were ascribed to rutile [20,46]. In addition, photocatalytic activity is commonly attributed to anatase, hence the interest in using $\mathrm{TiO}_{2}$ rich in this crystalline phase. On the other hand, the hexagonal wurtzite crystal phase presented peaks at $2 \theta=31.8^{\circ}, 34.3^{\circ}$, $36.5^{\circ}, 47.3^{\circ}, 56.5^{\circ}, 62.8^{\circ}, 68.3^{\circ}$, and $69.8^{\circ}$, which were indexed with their crystalline planes, respectively, according to the literature [21,47].

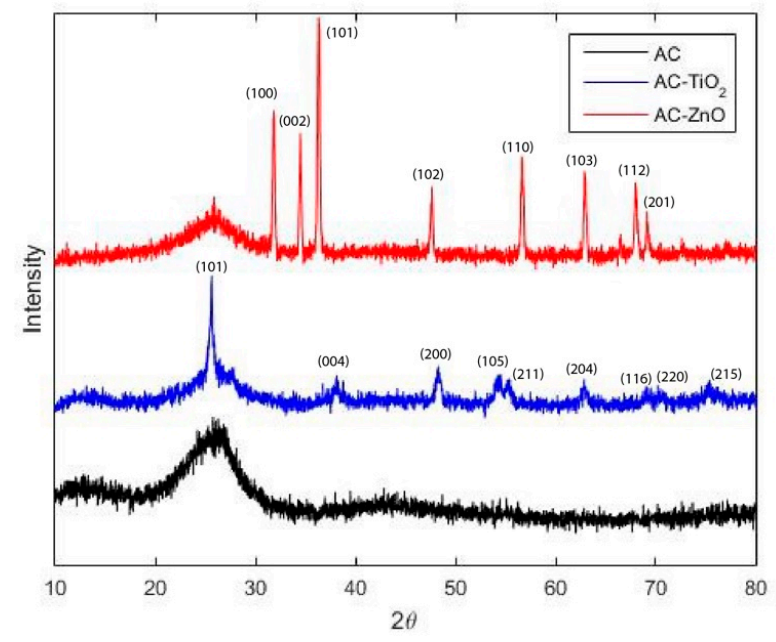

Figure 2. Powder X-ray diffraction (PXRD) patterns.

SEM micrographs are presented in Figure 3. A macropore channel network was observed in the AC structure (Figure 3A). In contrast, there was no presence of those channels in either of the composites, owing to metallic oxide deposition over the AC surface. It was possible to see some white and greyish zones in the composites micrographs, indicating surface heterogenicity (Figure 3B,C). The clearer regions corresponded to atoms with higher atomic number, since they scattered more electrons back towards the detector (BSE). In addition, the elements present in each one of the surfaces were identified carrying out an EDS mapping (Figure 3D,E). As expected, zinc and titanium atoms were found specifically in the brighter regions of the micrographs, proving that heavier atoms $(\mathrm{Zn}, \mathrm{Ti})$ scattered more electrons than the lighter ones. This was confirmed by EDS mapping and a map sum spectrum of each composite, in which the presence of each metal (Ti and $\mathrm{Zn}$ ) was detected in each composite, respectively.
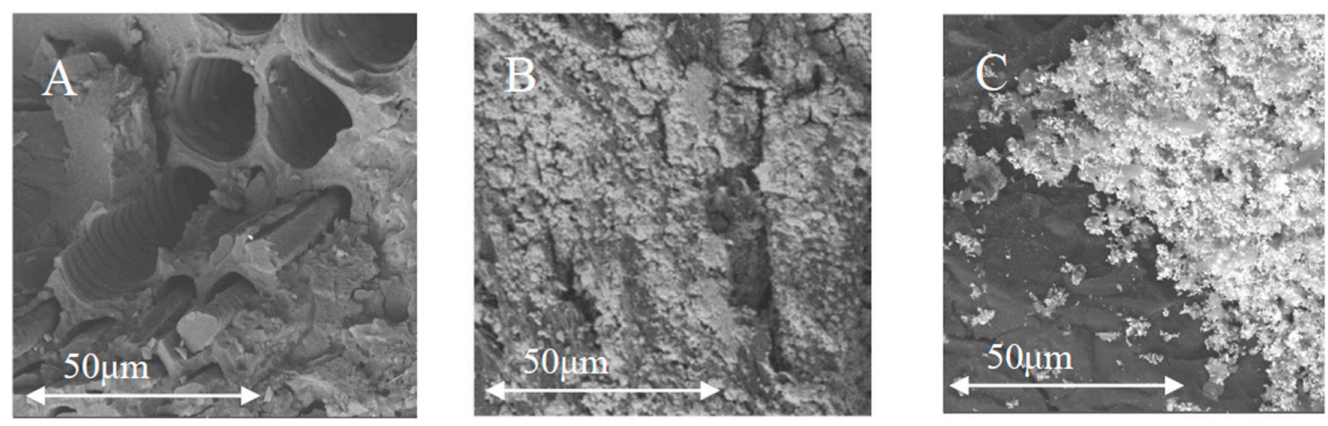

Figure 3. Cont. 

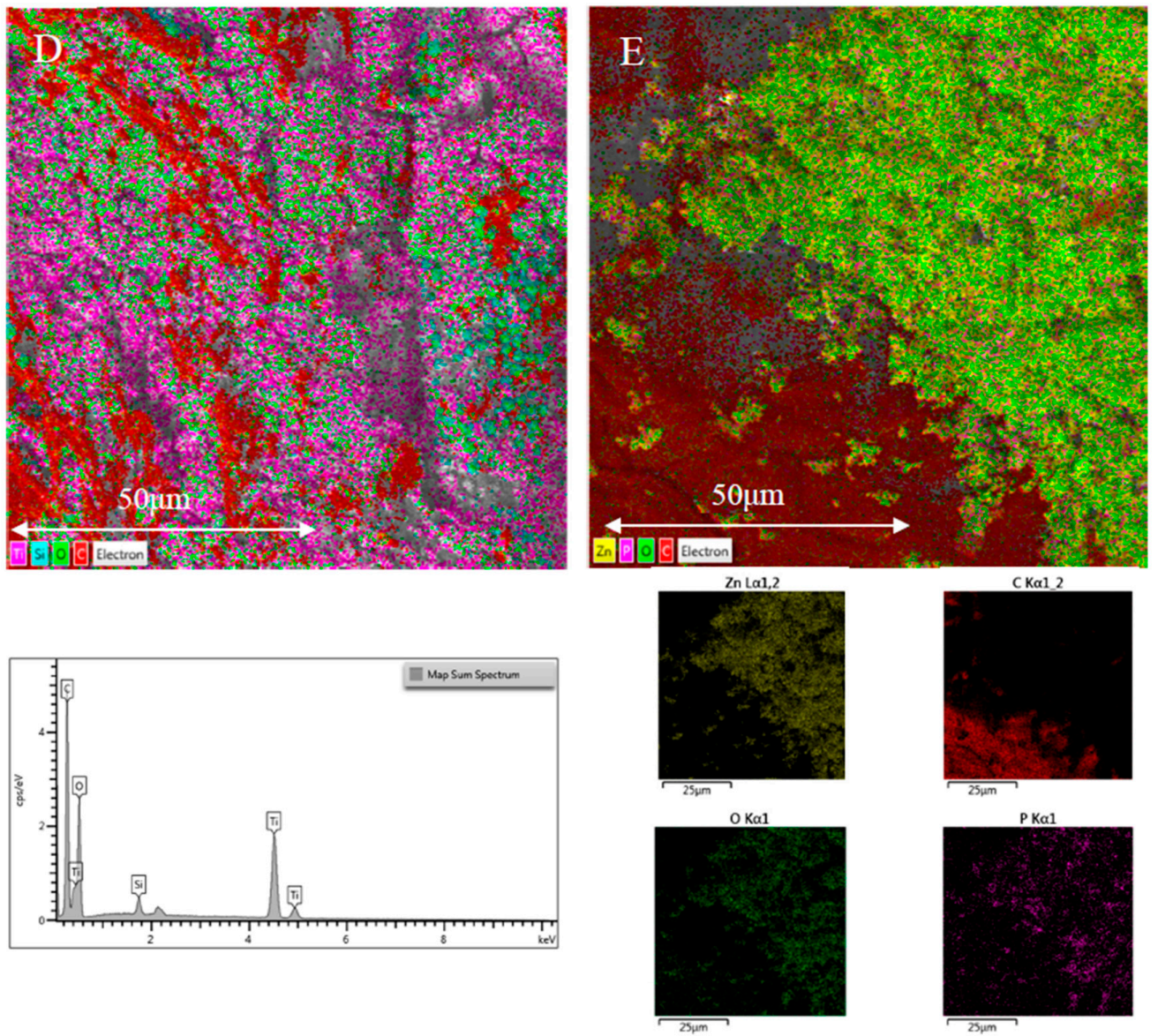

Figure 3. SEM micrographs taken with a working distance (WD) of $9.12 \mathrm{~mm}$, accelerating voltage for electrons (HV) of $10 \mathrm{kV}$, and backscattering electron detector (BSE) of (A) $\mathrm{AC},(\mathbf{B}) \mathrm{AC}^{-\mathrm{TiO}_{2}}$, and (C) AC-ZnO. EDS mapping and sum spectrum of (D) $\mathrm{AC}-\mathrm{TiO}_{2}$ and (E) $\mathrm{AC}-\mathrm{ZnO}$.

\subsubsection{Chemical Characterization}

Chemical surface characterization was accomplished using techniques of Fourier-transformed infrared spectroscopy (FT-IR), potentiometric titration, and UV-Vis diffuse reflectance spectroscopy (DRS). IR spectra (Figure 4) showed hydroxyl stretching mode $\left(2900-3500 \mathrm{~cm}^{-1}\right)$, carbonyl $\left(1700 \mathrm{~cm}^{-1}\right)$, aromatics $(C=C)\left(1590 \mathrm{~cm}^{-1}\right)$ bonds vibrations and hydroxyl bending mode $\left(1000-1500 \mathrm{~cm}^{-1}\right)$, which are functional surface groups normally present in AC [48]. The same bands appeared in the other spectra, but they differed in the fingerprint region, in which it was possible to identify the vibrational modes of metal-oxygen bonds. Those vibrations corresponded to bands at $650 \mathrm{~cm}^{-1}$ (Ti-O) and $500 \mathrm{~cm}^{-1}(\mathrm{Zn}-\mathrm{O})$, respectively $[49,50]$.

In addition, potentiometric titrations were carried out changing the $\mathrm{pH}$ between 3 and 11 . Figure 5 shows the pKa distribution of the functional surface groups presented in the solids and also displays the proton bindings curves. 


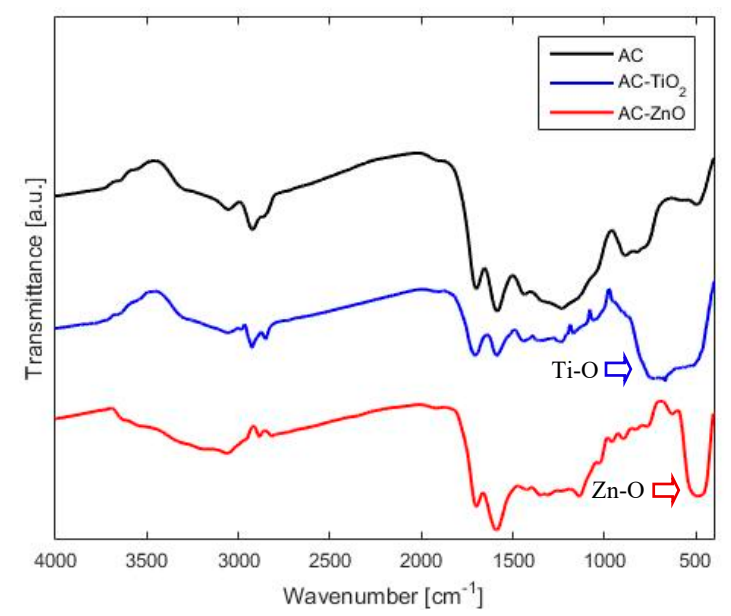

Figure 4. FT-IR spectra.
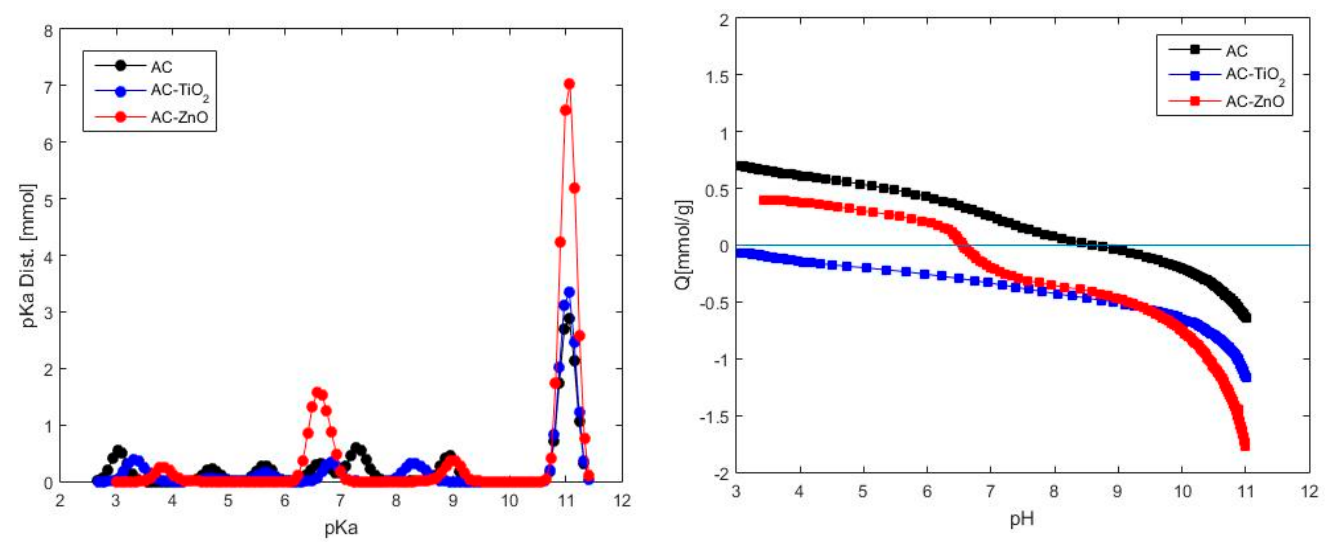

Figure 5. From left to right, pKa distribution and proton binding curves.

Potentiometric titrations allowed us to evaluate the acid-base behavior of the surface functional groups on the solids. Owing to surface heterogenicity of most activated carbons, acid dissociation constants $\left(K_{a}\right)$ depended directly on neighboring groups. In this case, $\mathrm{AC}$ and $\mathrm{AC}-\mathrm{TiO}_{2}$ presented two types of carboxylic groups, since they have two different $\mathrm{pKa}$ contributions when $\mathrm{pKa}$ is lower than 5 . Lactones and acid anhydride groups were designated to pKa range between 6 and 8, while the weaker acidic groups ( $\mathrm{pKa}>9$ ) corresponded to phenolic and carbonyl groups [51]. It is important to highlight that the metal oxides used were amphoteric and therefore they contributed to pKa distribution (i.e., $\mathrm{pKa}=7$ and 11). In accordance with the $\mathrm{pKa}$ distribution curves, it was possible to determine that $\mathrm{AC}-\mathrm{ZnO}$ was the solid with more acidic surface groups. However, the proton binding curve showed that $\mathrm{AC}-\mathrm{TiO}_{2}$ was the material with stronger acidic character because in the whole $\mathrm{pH}$ range its functional surface groups were deprotonated [52]. In contrast, AC functional groups were protonated until solution $\mathrm{pH}$ was around 9 . This behavior could be attributed to the amphoteric nature of the metal oxides [53].

On the other hand, UV-Vis diffuse reflectance spectroscopy was used to study photoactivity of each one of the materials. The spectra are presented in Figure 6, including a raw $\mathrm{TiO}_{2}$ spectrum for comparison. Owing to its black color, AC absorbs UV-Vis light in the whole range (200-700 nm) unlike $\mathrm{TiO}_{2}$ that reflects light above $350 \mathrm{~nm}$. Composites spectra have the same behavior of $\mathrm{TiO}_{2}$, but with a lower reflectance as a result of the carbonaceous matrix absorption. Semiconductors such as $\mathrm{ZnO}$ and $\mathrm{TiO}_{2}$ have an optical band gap that is equal to the threshold for photons to be absorbed. When a photon is absorbed, an electron from the valence band is promoted to the conduction band, generating a hole-electron pair with redox potential. From DRS spectra, the band gap could be obtained by applying the Kubelka-Munk function and using Tauc's plot [54]. Figure 6 also shows the Tauc plot considering 
a direct semiconductor. In each plot, a linear region appeared between 3 and $4 \mathrm{eV}$. According to the theory, an extrapolation of the linear region (same slope) gives the band gap, which is determined by the value in which the line passes through the $\mathrm{x}$ axis. That means that the band gap was equal to 2.9 and $3.1 \mathrm{eV}$ for the composites $\mathrm{AC}-\mathrm{TiO}_{2}$ and $\mathrm{AC}-\mathrm{ZnO}$, respectively. It is worth noting that there was a decrease in the calculated bandgap compared to the net $\mathrm{TiO}_{2}$, possibly due to the influence of the activated carbon surface. AC is a black material, so it absorbs light, influencing the band gap of the composite. Additionally, surface functional groups can induce a shift in the absorption spectra, changing the band gap value. This is in agreement with the results obtained by other authors using similar dark materials [55-58].
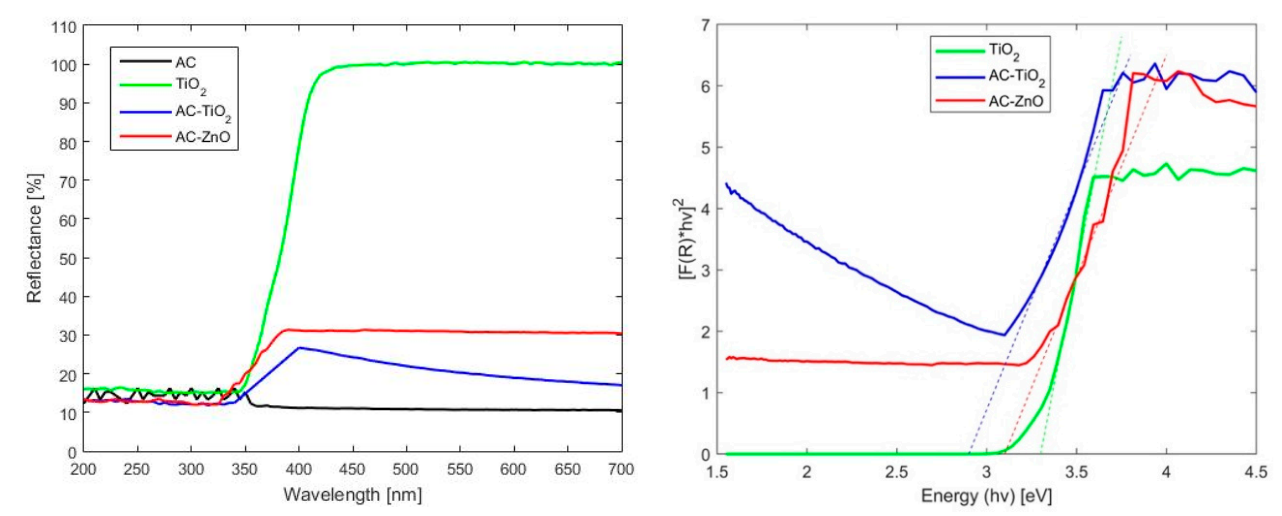

Figure 6. From left to right, DRS spectra and Tauc's plot.

\subsection{Phenol Adsorption and Photocatalysis}

Adsorption isotherms were used to study the relationship between equilibrium concentrations of an adsorbate over an adsorbent $\left(q_{e}\right)$ and in the residual solution $\left(C_{e}\right)$. Langmuir and Freundlich isotherm models were applied to fit the experimental data obtained when adsorption-desorption equilibrium was reached. In Table 2 all parameters of each model are presented, and in Figure 7 the isotherms and experimental data are plotted.

Table 2. Parameters calculated for Langmuir and Freundlich isotherm models.

\begin{tabular}{ccccc}
\hline Model & Parameter & AC & AC-TiO & AC-ZnO \\
\hline \multirow{2}{*}{ Langmuir } & $\mathrm{q}_{\mathrm{m}}\left(\mathrm{mg}^{2} \mathrm{~g}^{-1}\right)$ & 39.30 & 37.18 & 32.87 \\
& $\mathrm{~K}_{\mathrm{L}}\left(\mathrm{L} * \mathrm{mg}^{-1}\right)$ & 0.032 & 0.033 & 0.015 \\
& $\mathrm{~s}\left(\mathrm{mg}^{-1} \mathrm{~g}^{-1}\right)$ & 1.24 & 1.50 & 1.21 \\
\hline \multirow{3}{*}{ Freundlich } & $\mathrm{K}_{\mathrm{F}}$ & 2.72 & 2.83 & 1.13 \\
& $1 / \mathrm{n}$ & 0.55 & 0.52 & 0.62 \\
& $\mathrm{~s}\left(\mathrm{mg}^{-1} \mathrm{~g}^{-1}\right)$ & 1.78 & 0.86 & 1.43 \\
\hline
\end{tabular}

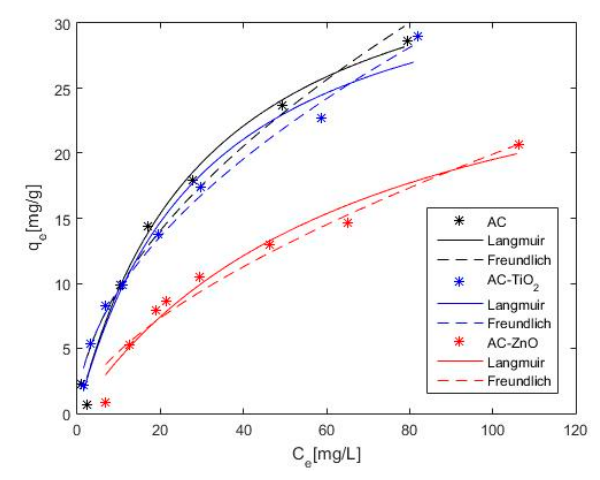

Figure 7. Adsorption isotherms of phenol at $298 \mathrm{~K}$. 
Considering that non-linear regressions (NLR) were applied to identify the model that best fits to the adsorption curves, the standard deviation were used. Langmuir was the model with the best fitting for $\mathrm{AC}$ and $\mathrm{AC}-\mathrm{ZnO}$. It was possible to compare both parameters given by the Langmuir isotherm. The parameter $q_{m}$ represents the monolayer maximum adsorption capacity, indicating that pristine AC could adsorb a higher amount of phenol, and in contrast, AC- $\mathrm{ZnO}$ presented the lowest adsorption capacity. This could be directly related to the BET surface area, since activated carbon presented the highest surface area and $\mathrm{AC}-\mathrm{ZnO}$ the lowest one. On the other hand, the Langmuir constant $K_{L}$ is an equilibrium constant that represents the adsorbate-adsorbent affinity. This means that because $K_{L}$ was smaller in $\mathrm{AC}-\mathrm{ZnO}$, phenol presented a better affinity to the pristine AC surface. With respect to $\mathrm{AC}-\mathrm{TiO}_{2}$, the Freundlich isotherm fit better with this experimental data. Originally, this model was proposed as an empirical equation, but it could be derived from a theorical footing. The principal assumption of this model is related to surface heterogeneity. In this case, surface topography was organized patch wise and sites with the same adsorption energies were grouped in each patch. The parameters $K_{F}$ and $\mathrm{n}$ are associated with adsorption capacity and surface heterogeneity, respectively. In this case, the solid $\mathrm{AC}-\mathrm{ZnO}$ was the one with the lower $K_{F}$ and thus the lower adsorption capacity. The parameter $1 / \mathrm{n}$ implied that all solids had an heterogeneous surface, due to $1 / \mathrm{n}$ being closer to unity than to zero [59].

Adsorption kinetics are used to describe the effects of contact time on the adsorption rate. Pseudo-first (PFO) and pseudo-second order (PSO) models were used to study adsorption kinetics, using NLR to calculate each one of the parameters. In Figure 8, experimental and fitted data are displayed. According to the standard deviation (Table 3), the PSO model adjusted better kinetic data for the three solids. From this model, the parameter $q_{e}$ was calculated, and it was equal to the amount of solute adsorbed per gram of adsorbent. As expected, AC- $\mathrm{ZnO}$ presented the lowest $q_{e}$ value since it had the smallest value of $q_{m}$ (Langmuir isotherm) and BET surface area. In contrast, the rate constant $k_{2}$ was slightly greater for $\mathrm{AC}-\mathrm{ZnO}$, which means a faster rate of adsorption in this solid. Typically, the PSO model describes chemisorption processes rather than physisorption, suggesting that electron exchange takes place during the adsorption process [60].

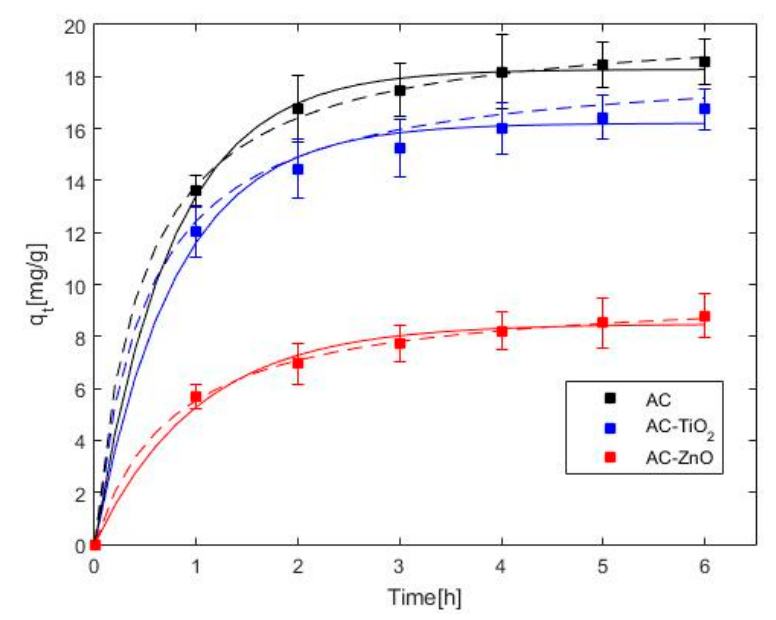

Figure 8. Adsorption kinetics of phenol. Dashed line (- -) is pseudo-first order (PFO) and solid line (-) is pseudo-second order (PSO) model. 
Table 3. Kinetic parameters of the model PFO and PSO.

\begin{tabular}{ccccc}
\hline & & AC & AC-TiO $_{2}$ & AC-ZnO \\
\hline \multirow{3}{*}{ Pseudo-first } & $\mathrm{qe}_{\mathrm{e}}\left(\mathrm{mg} \cdot \mathrm{g}^{-1}\right)$ & 18.27 & 16.20 & 8.48 \\
& $k_{1}\left(\mathrm{~h}^{-1}\right)$ & 1.32 & 1.26 & 0.98 \\
& $\mathrm{~s}\left(\mathrm{mg} \cdot \mathrm{g}^{-1}\right)$ & 0.29 & 0.46 & 0.31 \\
\hline \multirow{3}{*}{ Pseudo-second } & $\mathrm{q}_{\mathrm{e}}\left(\mathrm{mg}^{-1} \mathrm{~g}^{-1}\right)$ & 20.18 & 18.06 & 9.80 \\
& $k_{2}\left(\mathrm{~g} \cdot \mathrm{mg}^{-1} \mathrm{~h}^{-1}\right)$ & 0.11 & 0.11 & 0.13 \\
& $\mathrm{~s}\left(\mathrm{mg}^{-1} \mathrm{~g}^{-1}\right)$ & 0.20 & 0.10 & 0.19 \\
\hline
\end{tabular}

On the other hand, photocatalytic activity was studied by Langmuir-Hinshelwood first order kinetic model. To clarify, phenol photolysis was negligible under the experimental conditions used here. In Figure 9, the results of photocatalytic degradation are displayed, using as comparison the neat oxides $\left(\mathrm{TiO}_{2}\right.$ and $\left.\mathrm{ZnO}\right)$. Linear regression was employed to calculate the parameters of the Langmuir-Hinshelwood model, and the results are plotted in Figure 9. In relation to the first-order rate constants, it was determined that higher photocatalytic activity was achieved by the $\mathrm{AC}-\mathrm{TiO}_{2}$ composite, because its $k_{\text {app }}$ was greater $\left(0.0477 \mathrm{~h}^{-1}\right)$ than that for AC-ZnO $\left(0.0398 \mathrm{~h}^{-1}\right)$. This trend was also evidenced when neat oxide photoactivity was studied, indicating a better photocatalytic performance of titanium dioxide over zinc oxide. An important parameter known as quantum yield $\left(\phi(R)_{\lambda}\right)$ was used to compare between photocatalyst and photocatalytic systems. This parameter is calculated by dividing the number of products formed or reactants lost with the number of photons efficiently absorbed by the photocatalyst. However, in heterogeneous photocatalysis, it is difficult to obtain precisely the value of absorbed photons due to phenomena such as scattering and reflection of light. One possible approximation is the use of the apparent quantum yield, which uses the photons irradiated instead of photons absorbed [61]. In this case, the apparent quantum yield for $\mathrm{AC}-\mathrm{TiO}_{2}$ was 0.14 and for $\mathrm{AC}-\mathrm{ZnO}$ it was 0.11 . These are low values because the irradiated photons were higher than those actually absorbed by the photocatalysts. For that reason, some authors such as Horst Kisch recommended that for liquid/solid photocatalysis, optimal reaction rates should be measured to properly compare between photocatalysis systems [62,63].
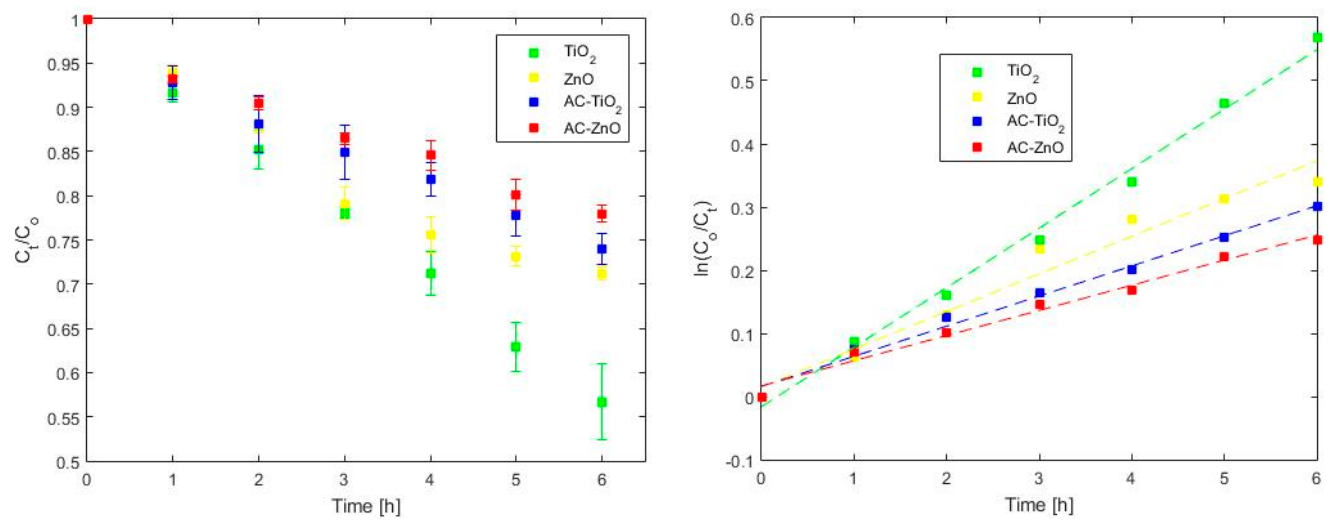

Figure 9. From left to right, kinetics of phenol photodegradation and first-order linear regression of the kinetic data (initial concentration, $50 \mathrm{ppm}$; lamp power, $9 \mathrm{~W}$; wavelength, $356 \mathrm{~nm}, 9.37 \times 10^{15}$ photons $\mathrm{cm}^{-2} \cdot \mathrm{min}^{-1}$; temperature, $\left.295 \mathrm{~K}\right)$.

Figure 10 corresponds to UV-Vis spectra of phenol at different times for the systems with $\mathrm{TiO}_{2}$ and $\mathrm{AC}-\mathrm{TiO}_{2}$; they show the effect of adsorption of phenol over the $\mathrm{AC}$ surface, and then the progress of photocatalysis. Additionally, it was possible to observe that the signal at $290 \mathrm{~nm}$ in the spectrum with $\mathrm{TiO}_{2}$ did not appear in the other spectrum. This could possibly be related to the adsorption of the by-products of phenol photodegradation over the available surface of AC. 

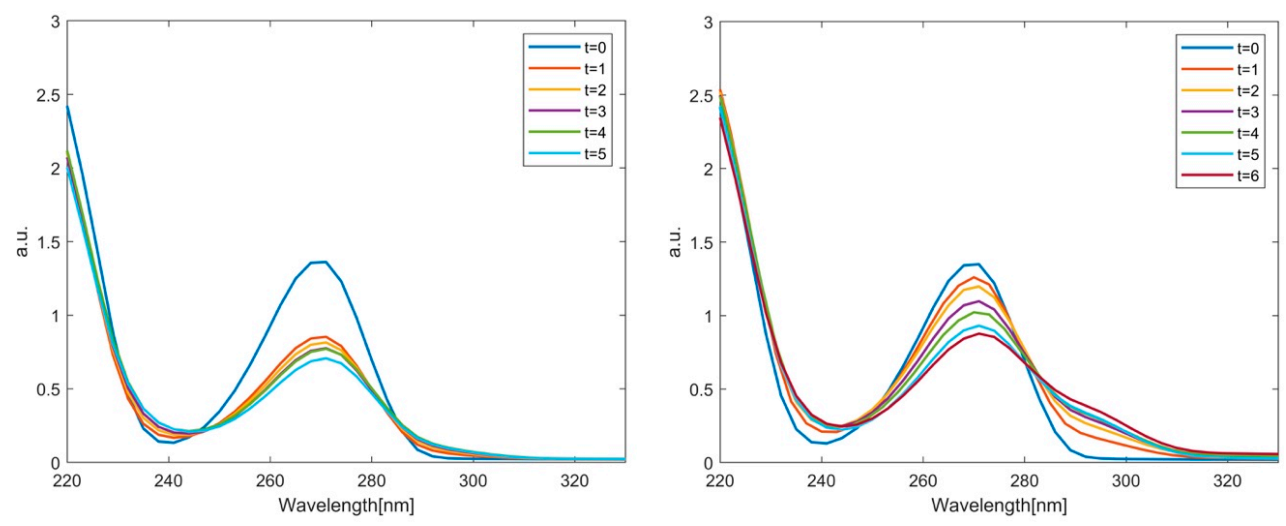

Figure 10. From left to right, UV-Vis spectra of phenol photodegradation over time for $\mathrm{AC}-\mathrm{TiO}_{2}$ and $\mathrm{TiO}_{2}$.

In order to compare the results with other carbon-based materials, a bibliography review was made. In 2018, Hepsiba Catherine et al. [64] synthetized graphene oxide from graphite flakes using the Hummers method. They reported a material with a low specific BET surface area $\left(0.727 \mathrm{~m}^{2} / \mathrm{g}\right)$ and phenol maximum adsorption capacity $\left(q_{m}\right)$ of $29.25 \mathrm{mg} / \mathrm{g}$. They concluded that the adsorption was dominated principally by van der Waals forces and $\pi-\pi$ interactions; however, they also reported that hydrogen bonds were also presented due to the oxygen surface functional groups. On the other hand, Weixue Wang and collaborators [65] in 2019 reported to have obtained nanoporous 3D-graphene oxide through a simple sugar-blowing route and post-oxidation. They reported a phenol $q_{m}$ of $135.6 \mathrm{mg} / \mathrm{g}$ and a BET surface area of $974.8 \mathrm{~m}^{2} / \mathrm{g}$. Graphenic materials have also been employed in heterogeneous photocatalysis. For example, Marta Pedrosa et al. [66] prepared graphene oxide (GO) from graphite comparing the Hummers' and the Brodie's methods. They concluded that GO prepared by Brodie's method is a successful way to obtain undoped metal-free photocatalyst for phenol photodegradation. Another study made by Chun-Chein Fu and collaborators [67] was about the synthesis of graphene oxide-titania composite by the hydrothermal method. They used this material both as an adsorbent and as a photocatalyst for phenol degradation. Their results show that the composite had a $q_{m}$ of $23.7 \mathrm{mg} / \mathrm{g}$ and excellent photocatalytic activity toward phenol. They concluded that the improved photoactivity could be attributed to the available adsorption sites and the low recombination rate of electron-hole pairs due to the composite's structure.

\section{Materials and Methods}

\subsection{Activated Carbon Preparation}

First, onion leaves were washed with enough water to remove dust and dirt. Then, the onions were dry in a home oven at $80^{\circ} \mathrm{C}$ for $15 \mathrm{~h}$. Chemical activation was used with phosphoric acid as an activation agent (See its characteristics in Table 4). A solution of $40 \%$ of phosphoric acid was prepared and mixed with the dry leaves, with an impregnation ratio of $20 \mathrm{~mL}$ of acid solution per gram of dry material and for $24 \mathrm{~h}$ of soaking time. The mixture was then dehydrated in an oven at $80^{\circ} \mathrm{C}$. The dried sample was pyrolyzed in a tubular furnace (Thermolyne 79,300), with a heating velocity of $1.5^{\circ} \mathrm{C} \cdot \mathrm{min}^{-1}$ until the maximum temperature of $450{ }^{\circ} \mathrm{C}$ was reached; it was left at this temperature for two hours. Finally, the AC was washed multiple times with hot and cold distilled water, until a neutral $\mathrm{pH}$ was reached. 
Table 4. Characteristics of the reagents and their respective CAS.

\begin{tabular}{ccccccc}
\hline $\begin{array}{c}\text { Metal Oxide } \\
\text { (MO) }\end{array}$ & CAS & $\begin{array}{c}\text { Molecular Mass } \\
\left(\mathbf{g} \cdot \mathbf{m o l}^{-\mathbf{1}} \mathbf{)}\right.\end{array}$ & Supplier & Purity & $\begin{array}{c}\text { Crystalline } \\
\text { Phase }\end{array}$ & $\begin{array}{c}\text { Particle Size } \\
\text { (nm) }\end{array}$ \\
\hline $\mathrm{TiO}_{2}$ & $13463-67-7$ & 79.87 & Sigma-Aldrich & $99 \%$ & Rutile-Anatase & 21 \\
$\mathrm{ZnO}$ & $1314-13-2$ & 81.39 & Sigma-Aldrich & $99 \%$ & Wurtzite & 50 \\
\hline
\end{tabular}

\subsection{Composites Preparation}

The wet impregnation method was used for preparation of composites. First, $30 \mathrm{~mL}$ of an ethanolic suspension of $A C$ was prepared by sonication. Then, each metal oxide (MO) was added using a mass ratio of 10:1.5 (AC:MO), with vigorous and continuous stirring for two hours. Solvent was removed under reduced pressure, and finally composites were washed with distilled water multiple times.

\subsection{Characterization}

\subsubsection{Physical Characterization}

Textural properties were determined by $\mathrm{N}_{2}$ physisorption isotherms at $-196^{\circ} \mathrm{C}$ in a semi-automatic Autorsorb IQ2 sorptometer (Quantachrome Instruments). BET and QSDFT models were applied to determine specific surface area, half pore width, and pore size distribution.

Powder X-ray diffraction (PXRD) was performed by Rigaku Miniflex diffractometer, with a radiation source of $\mathrm{Cu}(\mathrm{K} \alpha)$. The diffraction angle $(2 \theta)$ was varied from $10^{\circ}$ to $90^{\circ}$.

Scanning electron microscopy (SEM) and energy dispersive spectroscopy (EDS) was performed using a JSM 6490-LV JEOL microscope equipped with SE and BSE detectors.

\subsubsection{Chemical Characterization}

The surface chemistry of the samples was analyzed using Fourier-transform infrared spectroscopy, performed using a Thermo Scientific Nicolet Nexus spectrometer (Thermofisher, Boston, MA, USA) equipped with a diffuse reflectance cell. Spectra were recorded varying the wavenumber between 450 and $4000 \mathrm{~cm}^{-1}$. In addition, potentiometric titration was performed using a Titroline Alpha plus (Schott Instruments) automatic titrator. A solution of $\mathrm{NaCl} 0.01 \mathrm{M}(50 \mathrm{~mL})$ was used to suspend $100 \mathrm{mg}$ of each material. $\mathrm{HCl} 0.1 \mathrm{M}$ was used to adjust the initial $\mathrm{pH}$ to 3 . A solution of $\mathrm{NaOH}(0.1 \mathrm{M})$ was titrated until the final $\mathrm{pH}$ was equal to 11 .

Photoactivity of the composites was studied by UV-Vis diffuse reflectance spectroscopy using a UV-Vis Agilent Technologies Cary 100 spectrophotometer. The composites used had a particle size between 200 and $500 \mu \mathrm{m}$, and around $3 \mathrm{~g}$ of each one was placed in the DRS cell. To estimate the band gap energy of each material, a DRS integrating sphere was used, with a white standard of barium sulfate. Data was processed by applying the Kubelka-Munk equation.

\subsection{Adsorption Study}

A phenol stock solution (1000 ppm) was prepared by weighing $1.0 \mathrm{~g}$ of phenol and diluting it in $1.0 \mathrm{~L}$ of distilled water. Adsorption isotherms were made by using $10 \mathrm{~mL}$ of phenol solutions with different concentrations (5-200 ppm) and a dosage of each composite and AC of $1 \mathrm{~g} / \mathrm{L}$ at $295 \mathrm{~K}$ and neutral $\mathrm{pH}$. After adsorption-desorption equilibrium was achieved, the solid was filtered with PTFE of $0.22 \mu \mathrm{m}$, and the phenol concentration (in solution) was analyzed by UV/Vis spectrophotometry at $270 \mathrm{~nm}$. The data was studied and modeled by Langmuir and Freundlich isotherms.

$$
\begin{gathered}
q_{e}=\frac{q_{m} * K_{L} * C_{e}}{1+K_{L} * C_{e}} \\
q_{e}=K_{F} * C_{e}^{\frac{1}{n}}
\end{gathered}
$$




$$
q=\frac{\left(C_{0}-C\right) * V}{m}
$$

where $q_{e}$ is the equilibrium concentration of phenol over the adsorbent $(\mathrm{mg} / \mathrm{g}), C_{e}$ is the phenol equilibrium concentration in the liquid phase $(\mathrm{mg} / \mathrm{L}), K_{L}$ is the Langmuir constant $(\mathrm{g} / \mathrm{mg})$, and $K_{F}$ and $n$ are Freundlich adsorption parameters. Equation (3) is the definition of the solid phase concentration (adsorbate-adsorbent), where $V$ is the volume of the solution while $\mathrm{m}$ is the mass of the adsorbent.

Adsorption kinetics were studied in a $250 \mathrm{~mL}$ batch reactor using an initial concentration of phenol of $100 \mathrm{mg} / \mathrm{g}$ and a solid dosage of $1 \mathrm{~g} / \mathrm{L}$ at $295 \mathrm{~K}$ and neutral pH. Samples were taken every $60 \mathrm{~min}$ for $7 \mathrm{~h}$, and phenol concentration was followed by UV-Vis spectrophotometry. Results were modeled by PFO and PSO models (Equations (4) and (5)).

$$
\begin{gathered}
q=q_{e} *\left(1-e^{-k_{1} * t}\right) \\
q=\frac{k_{2} * q_{e}^{2} * t}{1+k_{2} * q_{e} * t}
\end{gathered}
$$

where $t$ is time (h) and $k_{1}$ and $k_{2}$ are the rate constant for PFO $\left(\mathrm{h}^{-1}\right)$ and PSO $(\mathrm{g} / \mathrm{mg} * \mathrm{~h})$, respectively.

\subsection{Photocatalysis}

Photocatalytic activity was studied in a $250 \mathrm{~mL}$ batch photo-reactor made of Pyrex and covered with an aluminum sheet, using an initial concentration of phenol of $100 \mathrm{mg} / \mathrm{g}$ and a solid dosage of $1 \mathrm{~g} / \mathrm{L}$ at $295 \mathrm{~K}$ and neutral $\mathrm{pH}$. The mixture was maintained for one hour in the dark to ensure adsorption-desorption equilibrium. Then, a UV lamp [68] with a power of $9 \mathrm{~W}$, a photon flux of $9.37 \times 10^{15}$ photons $\mathrm{cm}^{-2} \cdot \mathrm{min}^{-1}$, and a wavelength of $356 \mathrm{~nm}$ was turned on to begin photodegradation. Samples were taken every $60 \mathrm{~min}$ for $7 \mathrm{~h}$, and phenol concentration (in solution) was followed by UV-Vis spectrophotometry at $270 \mathrm{~nm}$. Results were modeled using the Langmuir-Hinshelwood first order kinetic model.

$$
-r_{\text {phenol }}=\frac{d C}{d t}=k_{\text {app }} C
$$

where $k_{\text {app }}$ is the rate constant of degradation $\left(\mathrm{h}^{-1}\right)$, and $r$ is the rate of degradation of phenol $(\mathrm{mg} / \mathrm{L} * \mathrm{~h})$.

\section{Conclusions}

Adsorption and photocatalytic activity of activated carbon and composites with metallic oxides $\left(\mathrm{TiO}_{2}\right.$ and $\left.\mathrm{ZnO}\right)$ were studied in the present work. Characterization studies confirmed that $\mathrm{AC}$ presents mesoporosity that is lost with the incorporation of metal oxides. There is a mesoporous filling by $\mathrm{TiO}_{2}$ and $\mathrm{ZnO}$ nanoparticles, leaving only some microporosity in their structure. This is strongly reflected in a decrease in BET surface area from $1100 \mathrm{~m}^{2} / \mathrm{g}$ to 440 and $218 \mathrm{~m}^{2} / \mathrm{g}$. According to SEM-EDS results, there is a surface heterogeneity in the composites due to non-homogeneous distribution of the oxides over the AC surface. Functional surface groups of AC were characterized as carboxylic, lactonic, anhydride, and principally weak acidic groups such as phenolic. Surface acidity was increased with the oxide's incorporation due to its amphoteric nature. The optical band gap was calculated to study their photoelectrical properties, and we obtained a decrease in the band gap compared to pristine $\mathrm{TiO}_{2}$.

The maximum adsorption capacity $\left(q_{m}\right)$ obtained from Langmuir isotherm was, in decreasing order, $\mathrm{AC}>\mathrm{AC}-\mathrm{TiO}_{2}>\mathrm{AC}-\mathrm{ZnO}$. This is directly related with the surface area of each solid. The adsorption kinetics follows the pseudo-second order model, which describes chemisorption over physisorption. Despite the higher adsorption capacity of $\mathrm{AC}-\mathrm{TiO}_{2}$ over $\mathrm{AC}-\mathrm{ZnO}$, adsorption was faster for $\mathrm{AC}-\mathrm{ZnO}$. First order rate constant was higher for $\mathrm{AC}-\mathrm{TiO}_{2}$ than for $\mathrm{AC}-\mathrm{ZnO}$, indicating a better photocatalytic activity. 
Author Contributions: D.F.H.-B. and J.P.R.-E. conceived and designed the experiments; D.F.H.-B. and J.P.R.-E. performed the experiments; D.F.H.-B., J.P.R.-E., J.C.M.-P., and R.S.R. analyzed the data; D.F.H.-B., J.P.R.-E., J.C.M.-P., and R.S.R. wrote the paper; D.F.H.-B., J.P.R.-E., J.C.M.-P., L.G., and R.S.R. critically revised the manuscript. All authors have read and agreed to the published version of the manuscript.

Funding: This research received no external funding.

Acknowledgments: The authors thank the framework agreement between the Universidad de Los Andes and the Universidad Nacional de Colombia-Sede Bogotá and the act of agreement established between the Chemistry Departments of both universities. The authors thank the "Fondo de apoyo Financiero para Doctorados" from Universidad de los Andes. Finally, the authors wish to express their gratitude to the Ministry of Science and Technology of Colombia (Minciencias) and its Call 811-2018 "Postdoctoral stay program for Colciencias training beneficiaries in SNCTeI entities". Additionally, the Juan Carlos Moreno-Piraján also appreciate the grant for the funding of research programs for Associate Professors, Full Professors, and Emeritus Professors announced by the Faculty of Sciences of the Universidad de los Andes (Colombia), 01-20-2020, 20-01-2022, according to the project INV-2019-84-1786.

Conflicts of Interest: The authors declare no conflict of interest.

\section{References}

1. Departamento Administrativo Nacional de Estadisticas (DANE). Boletín Mensual Insumos y Factores Asociados a la Producción Agropecuaria; Departamento Administrativo Nacional de Estadisticas: Bogotá, Colombia, 2013; Volume 17.

2. Üner, O.; Bayrak, Y. The effect of carbonization temperature, carbonization time and impregnation ratio on the properties of activated carbon produced from Arundo donax. Microporous Mesoporous Mater. 2018, 268, 225-234. [CrossRef]

3. Mohammed, A.A.; Chen, C.; Zhu, Z. Low-cost, high-performance supercapacitor based on activated carbon electrode materials derived from baobab fruit shells. J. Colloid Interface Sci. 2019, 538, 308-319. [CrossRef] [PubMed]

4. Raj, F.R.M.S.; Boopathi, G.; Jaya, N.V.; Kalpana, D.; Pandurangan, A. N, S codoped activated mesoporous carbon derived from the Datura metel seed pod as active electrodes for supercapacitors. Diam. Relat. Mater. 2020, 102, 107687. [CrossRef]

5. Hoang, V.C.; Dinh, K.N.; Gomes, V.G. Hybrid Ni/NiO composite with N-doped activated carbon from waste cauliflower leaves: A sustainable bifunctional electrocatalyst for efficient water splitting. Carbon N. Y. 2020, 157, 515-524. [CrossRef]

6. Guo, Y.; Tan, C.; Sun, J.; Li, W.; Zhang, J.; Zhao, C. Porous activated carbons derived from waste sugarcane bagasse for $\mathrm{CO}_{2}$ adsorption. Chem. Eng. J. 2020, 381, 122736. [CrossRef]

7. Lu, W.; Cao, X.; Hao, L.; Zhou, Y.; Wang, Y. Activated carbon derived from pitaya peel for supercapacitor applications with high capacitance performance. Mater. Lett. 2020, 264, 127339. [CrossRef]

8. Nourmoradi, H.; Moghadam, K.F.; Jafari, A.; Kamarehie, B. Removal of acetaminophen and ibuprofen from aqueous solutions by activated carbon derived from Quercus Brantii (Oak) acorn as a low-cost biosorbent. J. Environ. Chem. Eng. 2018, 6, 6807-6815. [CrossRef]

9. Mashile, G.P.; Mpupa, A.; Nqombolo, A.; Dimpe, K.M.; Nomngongo, P.N. Recyclable magnetic waste tyre activated carbon-chitosan composite as an effective adsorbent rapid and simultaneous removal of methylparaben and propylparaben from aqueous solution and wastewater. J. Water Process Eng. 2020, 33, 101011. [CrossRef]

10. Iriarte-Velasco, U.; Sierra, I.; Zudaire, L.; Ayastuy, J.L. Preparation of a porous biochar from the acid activation of pork bones. Food Bioprod. Process. 2016, 98, 341-353. [CrossRef]

11. Matos, J.; Fierro, V.; Montaña, R.; Rivero, E.; De Yuso, A.M.; Zhao, W.; Celzard, A. High surface area microporous carbons as photoreactors for the catalytic photodegradation of methylene blue under UV-vis irradiation. Appl. Catal. A Gen. 2016, 517, 1-11. [CrossRef]

12. Kwiatkowski, M.; Broniek, E. An analysis of the porous structure of activated carbons obtained from hazelnut shells by various physical and chemical methods of activation. Colloids Surf. A Physicochem. Eng. Asp. 2017, 529, 443-453. [CrossRef]

13. Zhang, L.; Pan, J.; Liu, L.; Song, K.; Wang, Q. Combined physical and chemical activation of sludge-based adsorbent enhances Cr(VI) removal from wastewater. J. Clean. Prod. 2019, 238, 117904. [CrossRef] 
14. Zhang, P.; Wang, J.; Fan, W.; Zhong, Y.; Zhang, Y.; Deng, Q.; Zeng, Z.; Deng, S. Ultramicroporous carbons with extremely narrow pore size distribution via in-situ ionic activation for efficient gas-mixture separation. Chem. Eng. J. 2019, 375, 121931. [CrossRef]

15. Il Kim, Y.; Lee, Y.J.; Yoo, J.; Kim, J.-H. High-capacitance activated bio-carbons with controlled pore size distribution for sustainable energy storage. J. Power Sources 2019, 438, 226969. [CrossRef]

16. Wang, Y.; Liu, M.; Zhao, X.; Cao, D.; Guo, T.; Yang, B. Insights into heterogeneous catalysis of peroxymonosulfate activation by boron-doped ordered mesoporous carbon. Carbon N. Y. 2018, 135, 238-247. [CrossRef]

17. Zhang, G.; Li, Z.; Zheng, H.; Fu, T.; Ju, Y.; Wang, Y. Influence of the surface oxygenated groups of activated carbon on preparation of a nano $\mathrm{Cu} / \mathrm{AC}$ catalyst and heterogeneous catalysis in the oxidative carbonylation of methanol. Appl. Catal. B Environ. 2015, 179, 95-105. [CrossRef]

18. Matos, I.; Bernardo, M.; Fonseca, I. Porous carbon: A versatile material for catalysis. Catal. Today 2017, 285, 194-203. [CrossRef]

19. Augugliaro, V.; Palmisano, G.; Palmisano, L.; Soria, J. Heterogeneous Photocatalysis and Catalysis. Heterog. Photocatal. 2019, 1, 1-24.

20. Ismael, M. Enhanced photocatalytic hydrogen production and degradation of organic pollutants from Fe (III) doped $\mathrm{TiO}_{2}$ nanoparticles. J. Environ. Chem. Eng. 2020, 8, 103676. [CrossRef]

21. Ismael, $\mathrm{M}$. The photocatalytic performance of the $\mathrm{ZnO} / \mathrm{g}-\mathrm{C}_{3} \mathrm{~N}_{4}$ composite photocatalyst toward degradation of organic pollutants and its inactivity toward hydrogen evolution: The influence of light irradiation and charge transfer. Chem. Phys. Lett. 2020, 739, 136992. [CrossRef]

22. Augugliaro, V.; Palmisano, G.; Palmisano, L.; Soria, J. Chapter 1-Heterogeneous Photocatalysis and Catalysis: An Overview of Their Distinctive Features. In Heterogeneous Photocatalysis; Marcì, G., Palmisano, L., Eds.; Elsevier: Amsterdam, The Netherlands, 2019; pp. 1-24, ISBN 978-0-444-64015-4.

23. Sadeghian, Z.; Hadidi, M.R.; Salehzadeh, D.; Nemati, A. Hydrophobic octadecylamine-functionalized graphene/ $/ \mathrm{TiO}_{2}$ hybrid coating for corrosion protection of copper bipolar plates in simulated proton exchange membrane fuel cell environment. Int. J. Hydrog. Energy 2020. [CrossRef]

24. Rouzafzay, F.; Shidpour, R.; Al-Abri, M.Z.M.; Qaderi, F.; Ahmadi, A.; Myint, M.T.Z. Graphene@ZnO nanocompound for short-time water treatment under sun-simulated irradiation: Effect of shear exfoliation of graphene using kitchen blender on photocatalytic degradation. J. Alloy. Compd. 2020, 829, 154614. [CrossRef]

25. Cui, W.; Bai, H.; Shang, J.; Wang, F.; Xu, D.; Ding, J.; Fan, W.; Shi, W. Organic-inorganic hybrid-photoanode built from NiFe-MOF and $\mathrm{TiO}_{2}$ for efficient PEC water splitting. Electrochim. Acta 2020, 2012, 136383. [CrossRef]

26. Cui, W.; Kang, X.; Zhang, X.; Cui, X. Gel-like ZnO/Zr-MOF(bpy) nanocomposite for highly efficient adsorption of Rhodamine B dye from aqueous solution. J. Phys. Chem. Solids 2019, 134, 165-175. [CrossRef]

27. El Bekkali, C.; Bouyarmane, H.; El Karbane, M.; Masse, S.; Saoiabi, A.; Coradin, T.; Laghzizil, A. Zinc oxide-hydroxyapatite nanocomposite photocatalysts for the degradation of ciprofloxacin and ofloxacin antibiotics. Colloids Surf. A Physicochem. Eng. Asp. 2018, 539, 364-370. [CrossRef]

28. Chong, R.; Fan, Y.; Du, Y.; Liu, L.; Chang, Z.; Li, D. Hydroxyapatite decorated $\mathrm{TiO}_{2}$ as efficient photocatalyst for selective reduction of $\mathrm{CO}_{2}$ with $\mathrm{H}_{2} \mathrm{O}$ into $\mathrm{CH}_{4}$. Int. J. Hydrog. Energy 2018, 43, 22329-22339. [CrossRef]

29. Ali, S.; Li, Z.; Chen, S.; Zada, A.; Khan, I.; Khan, I.; Ali, W.; Shaheen, S.; Qu, Y.; Jing, L. Synthesis of activated carbon-supported $\mathrm{TiO}_{2}$-based nano-photocatalysts with well recycling for efficiently degrading high-concentration pollutants. Catal. Today 2019, 335, 557-564. [CrossRef]

30. Muthirulan, P.; Meenakshisundararam, M.; Kannan, N. Beneficial role of ZnO photocatalyst supported with porous activated carbon for the mineralization of alizarin cyanin green dye in aqueous solution. J. Adv. Res. 2013, 4, 479-484. [CrossRef]

31. Nguyen, C.H.; Tran, H.N.; Fu, C.-C.; Lu, Y.-T.; Juang, R.-S. Roles of adsorption and photocatalysis in removing organic pollutants from water by activated carbon-supported titania composites: Kinetic aspects. J. Taiwan Inst. Chem. Eng. 2020. [CrossRef]

32. Schäffel, F. The Atomic Structure of Graphene and Its Few-layer Counterparts. In Graphene; Elsevier: Amsterdam, The Netherlands, 2013; Volume 25, pp. 5-59.

33. Warner, J.H.; Schäffel, F.; Bachmatiuk, A.; Rümmeli, M.H. Properties of Graphene. Graphene 2013, 25, 61-127.

34. Varghese, S.S.; Lonkar, S.; Singh, K.K.; Swaminathan, S.; Abdala, A. Recent advances in graphene based gas sensors. Sens. Actuators B Chem. 2015, 218, 160-183. [CrossRef] 
35. Korkmaz, S.; Kariper, A. Graphene and graphene oxide based aerogels: Synthesis, characteristics and supercapacitor applications. J. Energy Storage 2020, 27, 101038. [CrossRef]

36. Wang, J.; Song, J.; Mu, X.; Sun, M. Optoelectronic and Photoelectric Properties and Applications of Graphene-Based Nanostructures. Mater. Today Phys. 2020, 13, 100196. [CrossRef]

37. Zhu, W.; Lin, Y.; Kang, W.; Quan, H.; Zhang, Y.; Chang, M.; Wang, K.; Zhang, M.; Zhang, W.; Li, Z.; et al. An aerogel adsorbent with bio-inspired interfacial adhesion between graphene and MoS2 sheets for water treatment. Appl. Surf. Sci. 2020, 512, 145717. [CrossRef]

38. Gadipelli, S.; Guo, Z.X. Graphene-based materials: Synthesis and gas sorption, storage and separation. Prog. Mater. Sci. 2015, 69, 1-60. [CrossRef]

39. Ismael, M.; Wu, Y.; Taffa, D.H.; Bottke, P.; Wark, M. Graphitic carbon nitride synthesized by simple pyrolysis: Role of precursor in photocatalytic hydrogen production. New J. Chem. 2019, 43, 6909-6920. [CrossRef]

40. Ismael, M.; Wu, Y. A mini-review on the synthesis and structural modification of $\mathrm{g}-\mathrm{C}_{3} \mathrm{~N}_{4}$-based materials, and their applications in solar energy conversion and environmental remediation. Sustain. Energy Fuels 2019, 3, 2907-2925. [CrossRef]

41. Thommes, M.; Kaneko, K.; Neimark, A.V.; Olivier, J.P.; Rodriguez-Reinoso, F.; Rouquerol, J.; Sing, K.S.W. IUPAC Technical Report Physisorption of gases, with special reference to the evaluation of surface area and pore size distribution (IUPAC Technical Report). Pure Appl. Chem. 2015, 87, 1051-1069. [CrossRef]

42. Manoj, B.; Kunjomana, A.G. Study of Stacking Structure of Amorphous Carbon by X-Ray Diffraction Technique. Int. J. Electrochem. Sci. 2012, 7, 3127-3134.

43. Suphankij, S.; Mekprasart, W.; Pecharapa, W. Photocatalytic of N-doped $\mathrm{TiO}_{2}$ Nanofibers Prepared by Electrospinning. Energy Procedia 2013, 34, 751-756. [CrossRef]

44. Ansari, F.; Ghaedi, M.; Taghdiri, M.; Asfaram, A. Application of ZnO nanorods loaded on activated carbon for ultrasonic assisted dyes removal: Experimental design and derivative spectrophotometry method. Ultrason. Sonochem. 2016, 33, 197-209. [CrossRef] [PubMed]

45. Khatami, M.; Varma, R.S.; Zafarnia, N.; Yaghoobi, H.; Sarani, M.; Kumar, V.G. Applications of green synthesized $\mathrm{Ag}, \mathrm{ZnO}$ and $\mathrm{Ag} / \mathrm{ZnO}$ nanoparticles for making clinical antimicrobial wound-healing bandages. Sustain. Chem. Pharm. 2018, 10, 9-15. [CrossRef]

46. Ding, L.; Yang, S.; Liang, Z.; Qian, X.; Chen, X.; Cui, H.; Tian, J. TiO 2 nanobelts with anatase/rutile heterophase junctions for highly efficient photocatalytic overall water splitting. J. Colloid Interface Sci. 2020, 567, 181-189. [CrossRef] [PubMed]

47. Caglar, Y.; Caglar, M.; Ilican, S. XRD, SEM, XPS studies of Sb doped ZnO films and electrical properties of its based Schottky diodes. Optik 2018, 164, 424-432. [CrossRef]

48. El Mouchtari, E.M.; Daou, C.; Rafqah, S.; Najjar, F.; Anane, H.; Piram, A.; Hamade, A.; Briche, S.; Wong-Wah-Chung, $\mathrm{P}$. $\mathrm{TiO}_{2}$ and activated carbon of Argania Spinosa tree nutshells composites for the adsorption photocatalysis removal of pharmaceuticals from aqueous solution. J. Photochem. Photobiol. A Chem. 2020, 388, 112183. [CrossRef]

49. Omri, A.; Lambert, S.D.; Geens, J.; Bennour, F.; Benzina, M. Synthesis, Surface Characterization and Photocatalytic Activity of $\mathrm{TiO}_{2}$ Supported on Almond Shell Activated Carbon. J. Mater. Sci. Technol. 2014, 30, 894-902. [CrossRef]

50. Ullattil, S.G.; Periyat, P.; Naufal, B.; Lazar, M.A. Self-Doped ZnO Microrods-High Temperature Stable Oxygen Deficient Platforms for Solar Photocatalysis. Ind. Eng. Chem. Res. 2016, 55, 6413-6421. [CrossRef]

51. Gorgulho, H.F.; Mesquita, J.P.; Gonçalves, F.; Pereira, M.F.R.; Figueiredo, J.L. Characterization of the surface chemistry of carbon materials by potentiometric titrations and temperature-programmed desorption. Carbon N. Y. 2008, 46, 1544-1555. [CrossRef]

52. Bandosz, T.J.; Policicchio, A.; Florent, M.; Li, W.; Poon, P.S.; Matos, J. Solar light-driven photocatalytic degradation of phenol on S-doped nanoporous carbons: The role of functional groups in governing activity and selectivity. Carbon N. Y. 2020, 156, 10-23. [CrossRef]

53. Szekeres, M.; Tombácz, E. Surface charge characterization of metal oxides by potentiometric acid-base titration, revisited theory and experiment. Colloids Surf. A Physicochem. Eng. Asp. 2012, 414, 302-313. [CrossRef]

54. Nagamani, B.; Srinivasu, C. Physical parameters and structural analysis of titanium doped binary boro silicate glasses by spectroscopic techniques. Mater. Today Proc. 2019, 18, 2077-2083. [CrossRef] 
55. Apopei, P.; Orha, C.; Popescu, M.I.; Lazau, C.; Manea, F.; Catrinescu, C.; Teodosiu, C. Diclofenac removal from water by photocatalysis- assisted filtration using activated carbon modified with $\mathrm{N}$-doped $\mathrm{TiO}_{2}$. Process Saf. Environ. Prot. 2020, 138, 324-336. [CrossRef]

56. Varnagiris, S.; Medvids, A.; Lelis, M.; Milcius, D.; Antuzevics, A. Black carbon-doped $\mathrm{TiO}_{2}$ films: Synthesis, characterization and photocatalysis. J. Photochem. Photobiol. A Chem. 2019, 382, 111941. [CrossRef]

57. Park, Y.; Kim, W.; Park, H.; Tachikawa, T.; Majima, T.; Choi, W. Carbon-doped $\mathrm{TiO}_{2}$ photocatalyst synthesized without using an external carbon precursor and the visible light activity. Appl. Catal. B Environ. 2009, 91, 355-361. [CrossRef]

58. Wu, X.; Yin, S.; Dong, Q.; Guo, C.; Li, H.; Kimura, T.; Sato, T. Synthesis of high visible light active carbon doped $\mathrm{TiO}_{2}$ photocatalyst by a facile calcination assisted solvothermal method. Appl. Catal. B Environ. 2013, 142-143, 450-457. [CrossRef]

59. Ayawei, N.; Ebelegi, A.N.; Wankasi, D. Modelling and Interpretation of Adsorption Isotherms. J. Chem. 2017, 2017, 3039817. [CrossRef]

60. Heiba, H.F.; Taha, A.A.; Mostafa, A.R.; Mohamed, L.A.; Fahmy, M.A. Preparation and characterization of novel mesoporous chitin blended $\mathrm{MoO}_{3}$-montmorillonite nanocomposite for $\mathrm{Cu}$ (II) and $\mathrm{Pb}$ (II) immobilization. Int. J. Biol. Macromol. 2020, 152, 554-566. [CrossRef]

61. Hoque, M.A.; Guzman, M.I. Photocatalytic activity: Experimental features to report in heterogeneous photocatalysis. Materials 2018, 11, 1990. [CrossRef]

62. Kisch, H. On the problem of comparing rates or apparent quantum yields in heterogeneous photocatalysis. Angew. Chem. Int. Ed. 2010, 49, 9588-9589. [CrossRef]

63. Kisch, H.; Bahnemann, D. Best Practice in Photocatalysis: Comparing Rates or Apparent Quantum Yields? J. Phys. Chem. Lett. 2015, 6, 1907-1910. [CrossRef]

64. Catherine, H.N.; Ou, M.H.; Manu, B.; Shih, Y.H. Adsorption mechanism of emerging and conventional phenolic compounds on graphene oxide nanoflakes in water. Sci. Total Environ. 2018, 635, 629-638. [CrossRef] [PubMed]

65. Wang, W.; Gong, Q.; Chen, Z.; Wang, W.D.; Huang, Q.; Song, S.; Chen, J.; Wang, X. Adsorption and competition investigation of phenolic compounds on the solid-liquid interface of three-dimensional foam-like graphene oxide. Chem. Eng. J. 2019, 378, 122085. [CrossRef]

66. Pedrosa, M.; Da Silva, E.S.; Pastrana-Martínez, L.M.; Drazic, G.; Falaras, P.; Faria, J.L.; Figueiredo, J.L.; Silva, A.M.T. Hummers' and Brodie's graphene oxides as photocatalysts for phenol degradation. J. Colloid Interface Sci. 2020, 567, 243-255. [CrossRef] [PubMed]

67. Fu, C.C.; Juang, R.S.; Huq, M.M.; Hsieh, C. Te Enhanced adsorption and photodegradation of phenol in aqueous suspensions of titania/graphene oxide composite catalysts. J. Taiwan Inst. Chem. Eng. 2016, 67, 338-345. [CrossRef]

68. Murillo-Acevedo, Y.; Bernal-Sanchez, J.; Giraldo, L.; Sierra-Ramirez, R.; Moreno-Piraján, J.C. Initial Approximation to the Design and Construction of a Photocatalysis Reactor for Phenol Degradation with $\mathrm{TiO}_{2}$ Nanoparticles. Acs Omega 2019, 4, 19605-19613. [CrossRef]

(C) 2020 by the authors. Licensee MDPI, Basel, Switzerland. This article is an open access article distributed under the terms and conditions of the Creative Commons Attribution (CC BY) license (http://creativecommons.org/licenses/by/4.0/). 